\title{
Assessing the Inactivation of Salmonella in Dairy Wastewater at Varying Thermal Conditions
}

\author{
Sagor Biswas and Pramod Pandey
}

University of California, Davis, California.

\begin{abstract}
Elevated levels of Salmonella in dairy farm generated wastewater can contaminate food and water. Controlling the risk of Salmonella infection requires improving the existing understanding of Salmonella decay in impaired dairy wastewater. Enhanced understanding of Salmonella inactivation in dairy wastewater can help in deriving improved animal waste management practices capable of mitigating the risk of pathogen contamination to cropland as well as water resources. Considering the importance of the animal waste borne pathogen issue, the primary objective of the study was set to determine the degradation pattern of Salmonella in a mesophilic environment $\left(37^{\circ} \mathrm{C}\right)$. To do so, the impact of sampling timing (morning vs evening) on the changes in Salmonella counts were assessed. Further, a heat stress study was conducted to identify the critical die-off time at thermophilic temperatures $\left(48{ }^{\circ} \mathrm{C}\right.$ and $58{ }^{\circ} \mathrm{C}$ ). Results from the study showed that there was a $5.2 \log _{10}$ reduction in Salmonella count observed over the $14 \mathrm{~d}$ study period. There was no significant difference in Salmonella count during the sampling of morning or evening. Heat stress study showed that the first $30 \mathrm{~min}$ was the major die-off time. Regrowth of Salmonella was observed at a thermophilic temperature after $2 \mathrm{~d}$ further incubation. The outcome of the study will help to understand pathogen inactivation in dairy waste-water, and to derive improved animal waste treatment methods.
\end{abstract}

\section{Introduction}

The liquid and solid manures produced in feedlots such as dairy farms are great sources of nutrients and often used as fertilizers to enhance soil nutrients, and thus crop yields. Annually, 2.2 billion t cattle manure is generated in the United States, and potentially applied to croplands (USDA 2009; USDA 2014). While the application of animal manure to cropland reduces dependence on chemical fertilizer for replenishing soil nutrients, manure borne contamination such as pathogens also poses risks to water, soil and environmental health. Controlling the risk of contamination in vegetables and crops grown on land receiving manure as fertilizer (Tauxe 1997; Natvig et al. 2002; Erickson et al. 2014) and ambient water requires reducing pathogen and bacterial loads in manure.

In manure, the presence of many pathogens including E. coli 0157:H7, Salmonella spp., Campylobacter, Clostridium perfringens and Listeria monocytogens are reported (Zhao et al. 1995; Pell 1997). Food borne pathogens such as Salmonella and E. coli are known to be present in the gastrointestinal tracts of ruminant animals (Laven et al. 2003; Wells et al. 2001), leading to the sporadic shedding of these pathogens in their feces (Erickson et al. 2014; Rhoades et al. 2009) which can cause manure borne pathogen contamination, and thus infections.
Previously linkages between agricultural soils receiving animal manure and the risk to the microbiological safety of fresh produce have been shown (Ongeng et al. 2011; Bach et al. 2002; Hutchison et al. 2004). Increasing numbers of outbreak incidents are reported to have association with fresh vegetables and foodborne infections (Doyle and Erickson 2008; Barak et al. 2005; Beuchat 2002). Further, applying animal manure to cropland can contribute to microbial pollution in ambient water (Pandey et al. 2014; Soupir et al. 2006). Unmanaged runoff from cropland which receives manure as fertilizer can carry pathogens, which can contaminate shellfish areas and cause many water quality problems (USEPA 2012).

The linkages between manure application, pathogen contamination in crops (Natvig et al. 2002; Islam et al. 2004a, 2004b) and ambient water (Pandey et al. 2012) indicate the need for additional pathogen control measures with regard to manure management and its application for agricultural purposes. One option for controlling the transport of pathogens to food crops and water is that all manure must be treated prior to application as fertilizer (Erickson et al. 2014). Untreated manure or the manure, which have not been stored for sufficient time intervals for inactivating pathogens, can facilitate transfer of pathogens to ready-toeat crops (Islam et al. 2004a; Natvig et al. 2002; Toth et al. 2012), as well as to surface and ground water. Natvig et al. (2002) showed, using a controlled environment chamber study, that vegetables

Biswas, S. and P. Pandey. 2016. "Assessing the inactivation of Salmonella in dairy wastewater at varying thermal conditions." Journal of Water Management Modeling C394. doi: 10.14796/JWMM.C394.

(c) CHI $2016 \quad$ www.chijournal.org ISSN: 2292-6062 
such as arugula and radishes could be contaminated by applying bovine manure inoculated with Salmonella serovar Typhimurium or fecal Escherichia coli; however, the level of contamination on vegetables could be reduced by managing the timing of manure application and crop harvest.

Applying untreated dairy manure immediately after cattle excretion has a greater potential to contaminate vegetables and crops grown in the cropland, so the use of appropriate methods, capable of inactivating pathogens, is needed to reduce the risk of contamination. Methods such as drying (Amin-Nayyeri et al. 2010), aerobic digestion (Dumas et al. 2010), anaerobic digestion (Aitken et al. 2005; Popat et al. 2010; Pandey and Soupir 2011), composting (Maeda et al. 2010; Erickson et al. 2014), heat treatment (Shepherd et al. 2010; Garcia et al. 2010) and radiation treatment (Sinton et al. 2007; Brandon et al. 1977) are proposed for treating the manure and controlling manure borne pathogens.

Many factors, including $\mathrm{pH}$, temperature, mixing, non-mixing, feedstock, C:N (carbon:nitrogen) ratio, incubation time, aerobic condition and anaerobic environment, influence pathogen survival (Toth et al. 2012; Allievi et al. 1994; Pandey et al. 2015; Erickson et al. 2014; Kim et al. 2009; Harikishan and Sung 2003; Hipsey et al. 2008). However, one of the most important factors regulating the survival of pathogens is temperature, particularly when $\mathrm{pH}$ levels lie in the neutral range $(\mathrm{pH}=\sim 7.0)$ (John and Rose 2005; Hipsey et al. 2008).

In the dairy industry, excessive amounts of both liquid and solid manure (within the neutral $\mathrm{pH}$ range 6.5-8.0) are produced (Pandey et al. 2015). Figure 1 shows how this is typically handled.

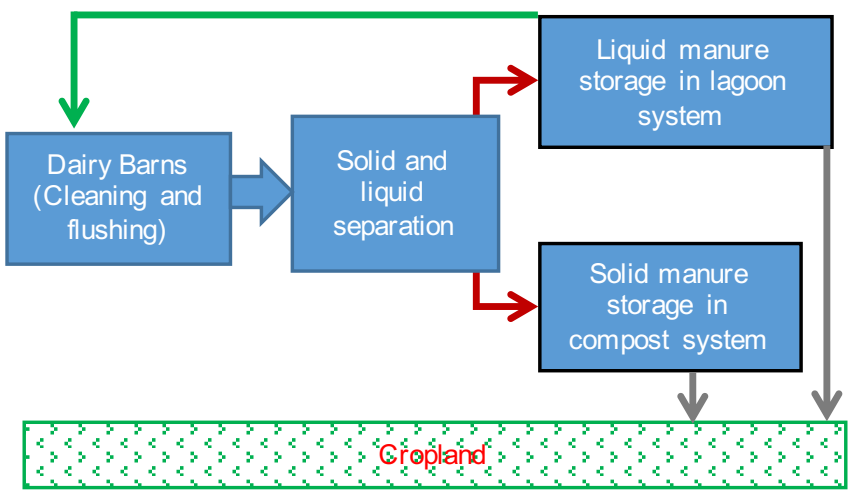

Figure 1 Flow of manure in a dairy system.

A considerable amount of water is used for cleaning and flushing the barns which house the cow herd, and subsequently the flushed water is collected in storage ponds (i.e. lagoon systems) before being applied to the cropland. The solid portion is stored in the form of compost piles. The flushed water includes feces, urine and bedding materials, which are also the major reservoir of pathogens (Murinda et al. 2004; Hutchison et al. 2005; Toth et al. 2013). The recycling of dairy wastewater (which is likely to have elevated bacterial loads and is stored in ponds) for cleaning the barns is a normal practice which also poses the risk of recirculation of pathogens. Previous research reported that pathogens can survive in dairy wastewater for extended periods of time (Kearney et al. 1993; Wang et al. 1996; Heinonen-Tanski et al. 1998; Himathongkham et al. 1999; Himathongkham and Riemann 1999; You et al. 2006).

Controlling dairy wastewater borne pathogens is critical because of the health risks associated with food and water borne pathogens. To mitigate Salmonella infections in food and water, improvement in the existing understanding of Salmonella decay in contaminated liquid and solid manure is needed. Enhanced understanding of Salmonella inactivation in dairy wastewater can help in deriving suitable treatment methods capable of controlling animal waste borne pathogens. To improve the understanding of wastewater borne Salmonella inactivation, a laboratory scale benchtop study was designed, and the impacts of various thermal conditions on Salmonella inactivation in dairy wastewater were assessed. The specific objectives of the study were:

- to determine the degradation pattern of Salmonella count in a mesophilic environment $\left(37^{\circ} \mathrm{C}\right)$;

- to evaluate the impact of the sampling event (morning vs evening) on Salmonella count; and

- to evaluate die-off time during heat stress testing in a thermophilic environment $\left(48^{\circ} \mathrm{C}\right.$ and $\left.58^{\circ} \mathrm{C}\right)$.

\section{Material and Methods}

\subsection{Feedstock Preparation}

Fresh dairy manure was collected from the on-campus dairy facility of the University of California, Davis. The fresh dairy manure was frozen at $-20^{\circ} \mathrm{C}$ and was thawed prior to the experiment. About $4.27 \mathrm{~kg}$ manure was thawed and mixed with $4.5 \mathrm{~L}$ of deionized water. The $\mathrm{pH}$ of the mixture was 7.27. The mixture was then sieved through a $850 \mu \mathrm{m}$ (ASTM \#20) mesh to separate the fibrous residue from the wastewater. The moisture content of the manure water was $98 \%$ with $\mathrm{pH}=7.7$.

\subsection{Experiment Setup}

A bench scale setup, shown in Figure 2, was designed using an overhead mixer (Carfamo Limited Model BDC 250), heating chamber and temperature sensor. Initially an inoculated wastewater sample was collected to enumerate the concentration of pathogens at the beginning of the experiment. The wastewater was placed inside a heating chamber to ensure constant heating at $37^{\circ} \mathrm{C}$. The wastewater was mixed continuously with the overhead mixture at $50 \mathrm{rpm}$. The inactivation of Salmonella typhimurium (ST) in wastewater was observed for 2 weeks. The samples of wastewater were collected twice (morning, 09:00, and evening, 16:00) during the first $3 \mathrm{~d}$ and once for the next $11 \mathrm{~d}$ incubation. For the heat stress study on d 10 of incubation, the incubated ( $10 \mathrm{~d}$ ) wastewater samples were placed in two additional chambers running at thermophilic temperatures $\left(48^{\circ} \mathrm{C}\right.$ and $58^{\circ} \mathrm{C}$ ) for $2 \mathrm{~h}$. The samples were collected at 30 min intervals to observe the inactivation of ST in dairy wastewater at elevated temperatures. 


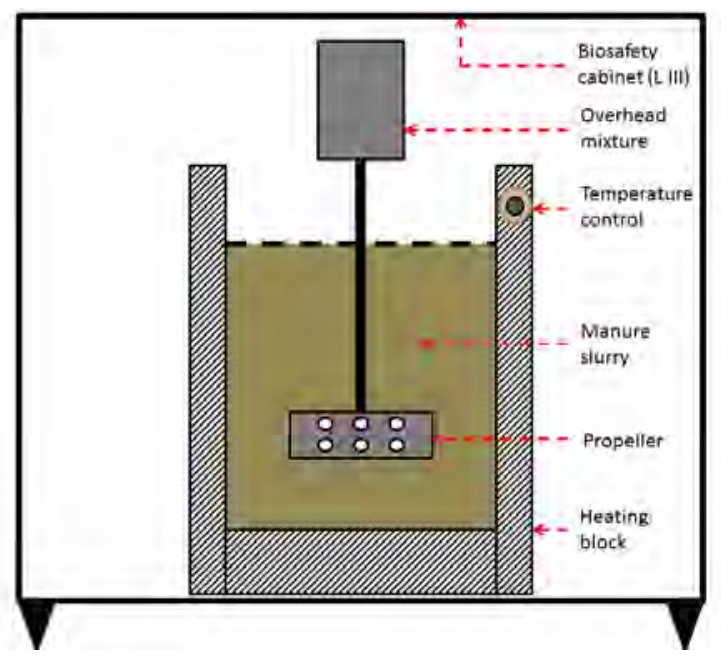

Figure 2 Schematic of experimental setup.

\subsection{Pathogen Inoculation, Enumeration and Sta- tistical Analysis}

Dairy wastewater was inoculated with the strain of Salmonella typhimurium LT2 (ATCC \# 700720). The ST was grown overnight in Luria-Bertani broth (Difco LB Broth, Miller; Becton, Dickinson and Company, Sparks, Maryland) on a bench top incubator shaker (MaxQ 4000, Thermo Scientific, Ohio) at $100 \mathrm{rpm}$ and $37^{\circ} \mathrm{C}$ for $24 \mathrm{~h}$. To ensure the quality control, a negative control of the respective growth media was used. The initial concentration of ST in inoculum was enumerated. Afterwards, $30 \mathrm{~mL}$ pure culture of ST was centrifuged at $10000 \mathrm{rpm}$ for $15 \mathrm{~min}$ to form the pellet. The pellet of ST was dissolved in $5 \mathrm{~mL}$ phosphate buffered saline (PBS), and then it was added and mixed (for $15 \mathrm{~min}$ ) with the dairy wastewater.

To enumerate the ST, the dairy wastewater sample was serially diluted in PBS, platted (duplicate), and incubated for $24 \mathrm{~h}$ at $35^{\circ} \mathrm{C}$ to ensure the ST growth before enumeration. ST enumeration was carried out following the Bacteriological Analytical Manual (BAM) protocol (USFDA 2014a). XLD (xylose lysine desoxycholate) agar (Becton, Dickinson and Company) was used for the isolation and differentiation of ST. The ST appears as red-yellow with black centre in the agar plates.

The first statistical analysis was conducted to evaluate the change in ST concentration at mesophilic temperature $\left(37^{\circ} \mathrm{C}\right)$ over the $14 \mathrm{~d}$ experiment. The second statistical analysis of ST was conducted to evaluate the impact of sampling events between morning and evening at $37{ }^{\circ} \mathrm{C}$ for the first $3 \mathrm{~d}$. The third analysis was performed to evaluate the change in ST concentration over time during the heat stress study at thermophilic temperatures. A comparative analysis of ST was carried out to evaluate the impact of sample timing on the heat stress study and among the three temperatures $\left(37^{\circ} \mathrm{C}, 48^{\circ} \mathrm{C}\right.$ and $\left.58^{\circ} \mathrm{C}\right)$ to evaluate the inactivation of ST in the late phase of the experiment (i.e. the last $4 \mathrm{~d}$ incubation) in mesophilic and thermophilic conditions. All the statistical analyses were performed using PROC GLIMMIX in SAS (Littell et al. 1996). An alpha level $a=0.05$ was used to identify significant differences among treatments by least significant difference methods.

\section{Results and Discussions}

\subsection{ST Inactivation in Dairy Wastewater at Meso- philic Environment}

The concentration of ST in the inoculated dairy wastewater (at room temperature) was $1.6 \times 10^{9} \mathrm{CFU} / \mathrm{mL}$, shown in Figure 3. Black bars indicate Salmonella levels. Small letters in the top of bars show statistical differences in the Salmonella typhimurium levels. Similar (alphabetically adjacent) letters show no differences, and different letters show significant differences at $a=0.05$.

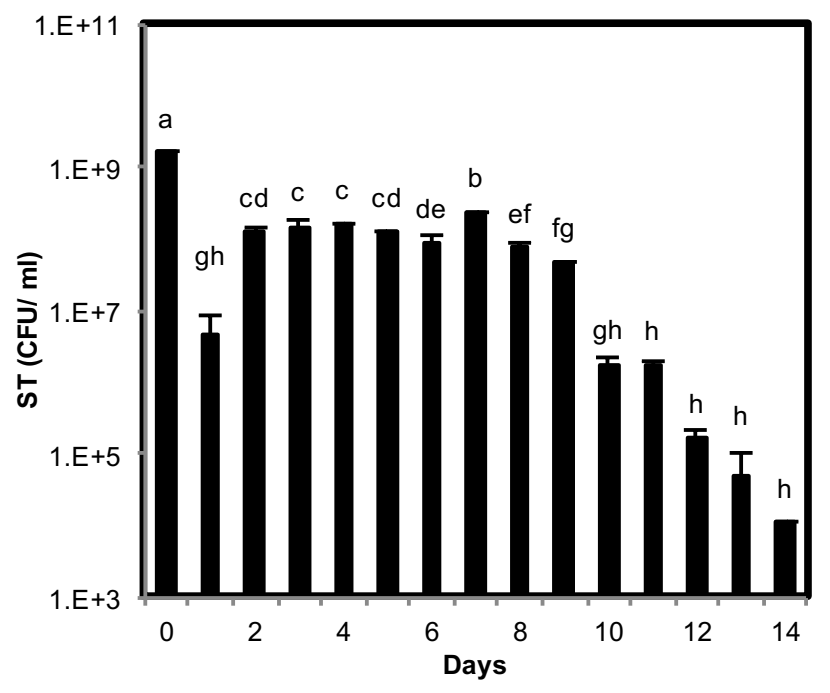

Figure 3 Changes in the levels of Salmonella typhimurium LT2 (average with standard error) in manure water at $37^{\circ} \mathrm{C}$.

The ST levels in wastewater were reduced significantly $(p<0.0001)$ over the $14 \mathrm{~d}$ incubation period at $37^{\circ} \mathrm{C}$. On the first day of incubation at $37^{\circ} \mathrm{C}$, the ST count reduced from $1.6 \times 10^{9} \mathrm{CFU} / \mathrm{mL}$ to $4.6 \times 10^{6} \mathrm{CFU} / \mathrm{mL}\left(2.5 \log _{10} \mathrm{CFU} / \mathrm{mL}\right.$ reduction). The ST count then increased and remained stable around $1.5 \times 10^{8} \mathrm{CFU} / \mathrm{mL}\left(8.2 \log _{10} \mathrm{CFU} / \mathrm{mL}\right.$ ) over the next $7 \mathrm{~d}$. Subsequently, the ST counts were reduced steadily $\left(4.3 \log _{10} \mathrm{CFU} / \mathrm{mL}\right.$ ) and reached the levels of $1.1 \times 10^{4} \mathrm{CFU} / \mathrm{mL}$ on $\mathrm{d} 14$. There was a $5.2 \log _{10}$ CFU/mL reduction in ST numbers over the course of the $14 \mathrm{~d}$ incubation period.

Several previous studies examined the inactivation pattern of Salmonella at different environmental and physiochemical conditions. You et al. (2006) studied the inactivation of a multidrug resistant Salmonella serovar Newport strain and a drug susceptible strain in dairy manure and found that the Salmonella count increased during the first $3 \mathrm{~d}$ incubation. Subsequently, the Salmonella levels decreased until $35 \mathrm{~d}$ incubation. A rapid 
drop in concentration to below detection level was observed by $49 \mathrm{~d}$ ( $184 \mathrm{~d}$ by the most probable number method) under ambient temperature conditions $\left(24.5^{\circ} \mathrm{C} \pm 1.4^{\circ} \mathrm{C}\right)$ with changing moisture (weekly loss $<3 \%$ total weight). Toth et al. (2011) found a comparable survival pattern of Salmonella where the increase in concentration was followed by a steady log-linear decline phase, and finally a long tailing phase of low Salmonella concentrations. The authors observed that Salmonella can survive $>137 \mathrm{~d}$ (by the most probable number method) in the effluent of a dairy lagoon under the natural conditions of southeastern Pennsylvania. The log reduction time (days required for a $90 \%$ reduction of concentration) was reported to be $7 \mathrm{~d}$.

The survival pattern of ST in the current study differs from the patterns of Salmonella reductions reported by Toth et al (2011) and You et al. (2006), which can be attributed to the differences in dairy wastewater. Additionally, the current study was executed in a controlled condition reducing the risk of an ambient environment. The decline in ST concentration was not log linear over the incubation period. A study by Kearney et al. (1993) found that the decline in Salmonella count in cattle slurry was temperature dependent during a $135 \mathrm{~d}$ storage period. They found that Salmonella levels declined faster at an elevated temperature $\left(17^{\circ} \mathrm{C}\right.$ vs $\left.4^{\circ} \mathrm{C}\right)$. The period required to achieve a $1 \log _{10}$ unit reduction was $21.3 \mathrm{~d}$ at $4{ }^{\circ} \mathrm{C}$ compared to $17.5 \mathrm{~d}$ at $17^{\circ} \mathrm{C}$. Another study by Himathongkham et al. (1999) found a long reduction time of $12.7 \mathrm{~d}$ for Salmonella in dairy manure slurry at $20^{\circ} \mathrm{C}$. The $\mathrm{pH}$ of dairy wastewater varied within the range 7.6 to 8.0 during the time of experiment. You et al. (2006) found that the increase in pH from 6.7 (at $0 \mathrm{~d}$ ) to 7.6 (at $37 \mathrm{~d}$ ) and 8 (at $72 \mathrm{~d}$ ) was linked with the decrease in Salmonella count. Other studies, such as Himathongkham et al. (1999) and Wang et al. (1996), also reported possible relationship between the increases in $\mathrm{pH}$ with the decline in pathogen concentration.

The dry matter content in the dairy wastewater was 3\% to $4 \%$ for this experiment. Hutchison et al (2005) found that $7 d$ and $9 \mathrm{~d}$ of incubation (correspondingly) was required to incur a 1 log reduction in concentration when Salmonella spp. inoculated dairy slurries containing high (7.2\%) and low (2.1\%) amounts of dry matter were exposed at atmospheric temperature in storage tanks. The authors predicted that the phenomenon of drying, rather than other parameters such as dry matter, ould be a crucial influence on the survival of Salmonella in dairy slurry. Nicholson et al (2005) found a maximum Salmonella survival of $32 \mathrm{~d}$ in dairy slurry with $7 \%$ dry matter compared to $93 \mathrm{~d}$ survival in dairy slurry with $2 \%$ dry matter at temperature $\sim 20^{\circ} \mathrm{C}$. However, a laboratory scale study by Jones (1976) found a longer survival time of Salmonella in cattle slurry containing $5 \%$ dry matter as compared to $1 \%$.

\subsection{Diurnal Effect on ST Inactivation in Meso- philic Temperature}

The ST levels in morning and evening samples are shown in Figure 4 , and indicate the change in ST levels within a day. Black bars indi- cate Salmonella levels in samples collected in the evening. Hollow bars indicate Salmonella levels in samples collected in the morning. Small letters in the top of bars show statistical differences in the Salmonella typhimurium levels. Similar (alphabetically adjacent) letters show no differences, and different letters show significant differences at $a=0.05$.

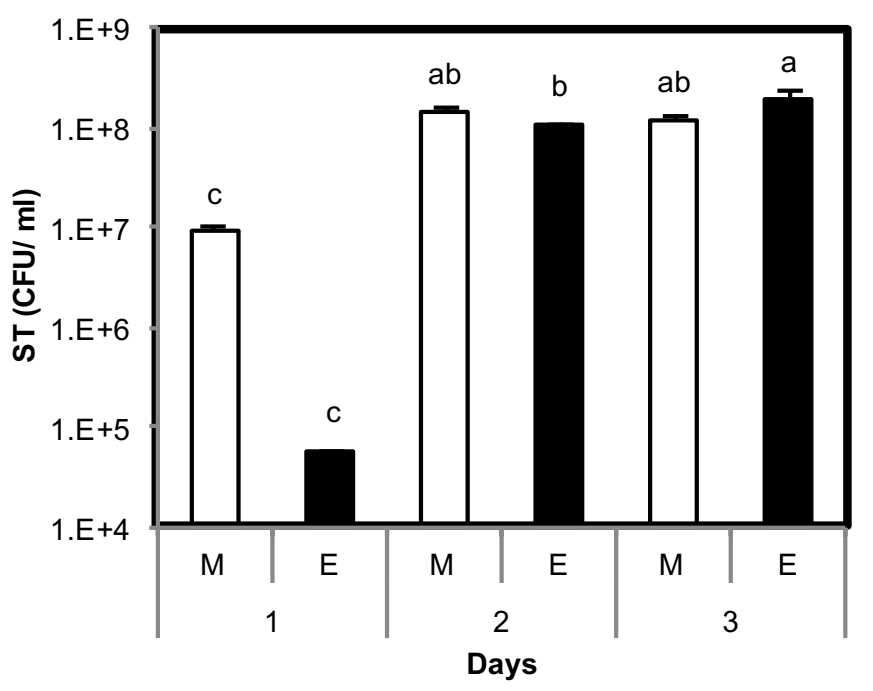

Figure 4 Changes in concentration of Salmonella typhimurium (average with standard error) in manure water at $37^{\circ} \mathrm{C}$ during the first $3 \mathrm{~d}$ of the experiment.

While analyzing the morning and evening samples, there was no significant interaction between day and time of the sampling period ( $p=0.062$ ). However, there was significant difference in the total count of ST at different days $(p<0.002)$. The count of ST was low in $d 1$ compared to $d 2$ and $d 3$ (Figure 4). Thus, the average count of ST may not change over a short span of time of $\leq 8 \mathrm{~h}$, but it may change over a longer duration such as $\geq 24 \mathrm{~h}$, which emphasizes that ST inactivation may not occur drastically in a mesophilic temperature at $37^{\circ} \mathrm{C}$ in dairy wastewater.

\subsection{Impact of Heat Stress Post Treatment on ST Inactivation}

The reduction in ST levels during of heat stress test (on d 10) is shown in Figure 5 below. Black bars indicate Salmonella levels in samples collected during heat stress testing at $58^{\circ} \mathrm{C}$. Hollow bars indicate Salmonella levels in samples collected during heat stress testing at $48^{\circ} \mathrm{C}$. Similar (alphabetically adjacent) letters show no differences, and different letters show significant differences at $a=0.05$.

The initial concentration of ST was $1.8 \times 10^{6} \mathrm{CFU} / \mathrm{mL}$ in dairy wastewater. Overall, there was no significant interaction between temperature and time of sampling ( $p=0.999)$ during the heat stress study. However, a significant reduction in ST levels was observed after the first $30 \mathrm{~min}$ incubation at $48^{\circ} \mathrm{C}$ and $58^{\circ} \mathrm{C}$. The heat stress study showed that there was a $1.4 \log _{10}$ reduction from initial concentration after $30 \mathrm{~min}$ incubation at $48^{\circ} \mathrm{C}$, and a $2.5 \log _{10}$ reduction from initial concentration after $30 \mathrm{~min}$ incubation at $58^{\circ} \mathrm{C}$. 


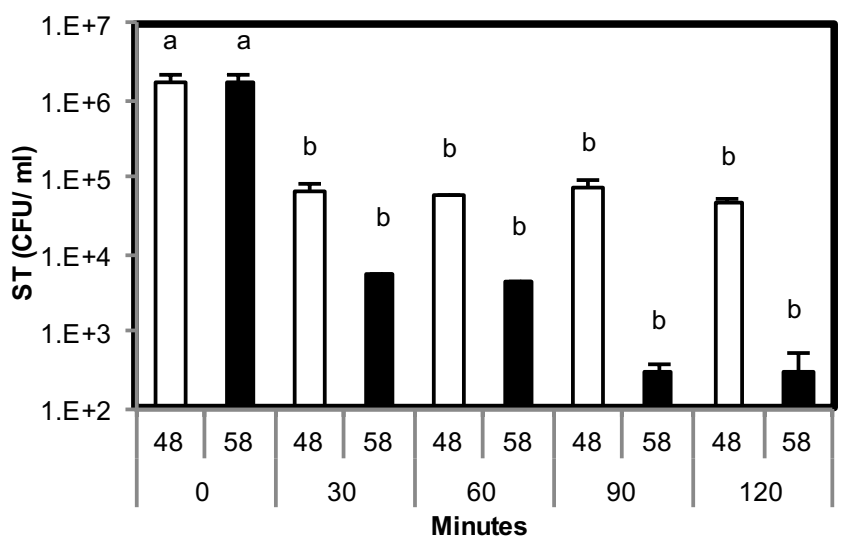

Figure 5 Changes in concentrations of Salmonella (average with standard error) in manure water in heat stress test at $48^{\circ} \mathrm{C}$ and $58^{\circ} \mathrm{C}$.

After $30 \mathrm{~min}$, the ST concentrations remained steady until $120 \mathrm{~min}$ and then there was significant difference in concentrations between the temperatures. During the time of heat stress testing, the reduction in ST concentration was more consistent and it went from $1.8 \times 10^{6} \mathrm{CFU} / \mathrm{mL}$ at $0 \mathrm{~min}$ to $3.1 \times 10^{2} \mathrm{CFU} / \mathrm{mL}$ at $120 \mathrm{~min}$ at $58^{\circ} \mathrm{C}$. The results showed that the major die-off occurred during the initial phase of heating and within a short span of time at elevated temperature. Olsen and Larsen (1987) found that the time required for $90 \%$ decimation of Salmonella was $0.6 \mathrm{~d}$ to $0.9 \mathrm{~d}$ in anaerobic digestion of cattle slurry at $53^{\circ} \mathrm{C}$. Himathongkham et al. (1999) concluded that at lower temperatures $\left(4{ }^{\circ} \mathrm{C}, 20^{\circ} \mathrm{C}\right.$ and $37^{\circ} \mathrm{C}$ ), the decimal reduction of Salmonella can be achieved in $65.8 \mathrm{~d}, 2.8 \mathrm{~d}$ and $2.5 \mathrm{~d}$ respectively.

During the last phase of the experiment perturbation of the ST was observed in both $48^{\circ} \mathrm{C}$ and $58^{\circ} \mathrm{C}$, shown in Figure 6. Gray bars indicate Salmonella levels in samples collected from the study at $37^{\circ} \mathrm{C}$. Hollow bars indicate Salmonella levels in samples collected during heat stress test at $48^{\circ} \mathrm{C}$. Black bars indicate Salmonella levels in samples collected during heat stress test at $58^{\circ} \mathrm{C}$. Similar (alphabetically adjacent) letters show no differences, and different letters show significant differences at $a=0.05$.

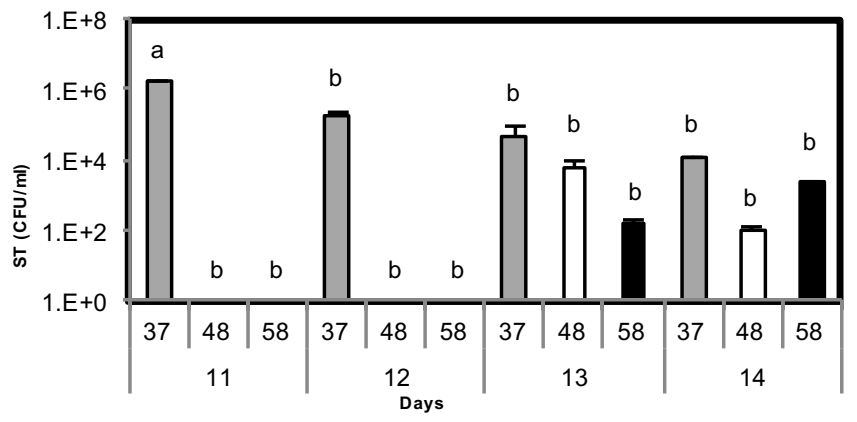

Figure 6 Concentrations of Salmonella typhimurium (average with standard error) at $37^{\circ} \mathrm{C}, 48^{\circ} \mathrm{C}$ and $58^{\circ} \mathrm{C}$ in last $4 \mathrm{~d}$ of experiment.
The concentrations of ST (on d 11 ) at $37^{\circ} \mathrm{C}, 48^{\circ} \mathrm{C}$ and $58^{\circ} \mathrm{C}$ were $1.8 \times 10^{6} \mathrm{CFU} / \mathrm{mL}, 4.8 \times 10^{4} \mathrm{CFU} / \mathrm{mL}$ and $3.1 \times 10^{2} \mathrm{CFU} / \mathrm{mL}$ respectively. While comparing the three incubation temperatures $\left(37^{\circ} \mathrm{C}, 48^{\circ} \mathrm{C}\right.$ and $58^{\circ} \mathrm{C}$ ) during the last four days (d 11, d 12, d 13 and $d$ 14) of the experiment; there was a significant interaction between temperature and day $(p<0.0001)$.

The ST level was not detected in dairy wastewater on $\mathrm{d} 11$ and $\mathrm{d} 12$ at $48^{\circ} \mathrm{C}$ and $58^{\circ} \mathrm{C}$. A sudden perturbation (i.e. increase in the concentrations of ST) was observed at both temperatures $\left(48^{\circ} \mathrm{C}\right.$ and $58^{\circ} \mathrm{C}$ ) during $\mathrm{d} 13$ and $\mathrm{d} 14$, indicating a potential regrowth. Shepherd et al. (2010) evaluated the effect of heat shock $\left(55^{\circ} \mathrm{C}\right)$ on ST in dairy manure compost with vegetables under field conditions and found that heat stressed ST survived an additional $2 \mathrm{~d}$ during summer and $60 \mathrm{~d}$ during winter compared to non-heat shocked $\left(30^{\circ} \mathrm{C}\right) \mathrm{ST}$. Further studies are required to enhance the understanding of the regrowth of ST in dairy wastewater. While this study showed clearly that post treatment (after $10 \mathrm{~d}$ incubation at mesophilic temperature) of wastewater at elevated temperature (for $120 \mathrm{~min}$ ) reduced the ST numbers considerably $\left(\sim 1.6 \log _{10}\right.$ reduction at $48^{\circ} \mathrm{C}$ and $3.8 \log _{10}$ reduction at $\left.58^{\circ} \mathrm{C}\right)$, and thus that the post treatment can be an effective method of controlling ST within a short period of time. Improved understanding is needed to reduce the risk of potential regrowth of ST in dairy wastewater.

The study was focused on assessing the impacts of temperature on ST inactivation due to the fact that temperature plays a crucial role in bacteria die-off. In addition to temperature, many other physical and chemical parameters (including change in $\mathrm{pH}$, aerobic condition, anaerobic condition, mixing and non-mixing) control pathogen survival. Considering the enormous amount of dairy wastewater produced by the dairy industry, however, the use of chemical processes resulting in altering the $\mathrm{pH}$ is less likely to be an acceptable alternative for controlling pathogens in dairy manure. Further, changing the $\mathrm{pH}$ of dairy manure will require a large quantity of chemicals due to the high buffering capacity of manure (Angelidaki et al. 1993; Georgakakis et al. 1974).

Although, during the thermal inactivation, regrowth of Salmonella was observed at a later phase of the experiment (Figure 6), temperature driven inactivation is a viable and relatively simpler option for controlling the potential risk of foodborne pathogens such as Salmonella. Increased awareness of food borne pathogens and potential pathogen contamination caused by manure will likely to lead to limiting untreated manure application as fertilizer. If pathogen control restrictions are in place, the application of manure as fertilizer will largely depend on the availability of cost effective and simpler solutions for pathogen inactivation in manure.

Therefore identifying an improved method for pathogen control in manure is important. Pathogens such as Salmonella can seriously affect anyone, but for pregnant women and their fetuses, pathogens can be particularly harmful_even fatal (USFDA 2014b). Salmonella is the second most common cause of single etiology outbreaks and illnesses in the United States 
and Salmonella alone causes more than 1.2 million infections each year, which account for $\$ 365$ million in direct medical costs (CDC 2014). In 2012, Salmonella accounted for $25 \%$ of foodborne disease outbreaks, and $33 \%$ of illnesses which caused the most (64\%) foodborne outbreak related hospitalizations in the United States (CDC 2014). It is not only a human health hazard but also responsible for clinical diseases in cattle like fever and diarrhoea (Smith 2002; Toth et al. 2011).

Many current manure treatment processes requires extensive time for reducing pathogens. Previous studies showed Salmonella survival in manure for extended periods of time. Toth et al. (2011) found survival of Salmonella enterica in dairy farm environments $>137 \mathrm{~d}$. Another study by Baloda et al. (2001) showed that Salmonella could survive $\leq 299 \mathrm{~d}$. A study by Jones (1976) reported that Salmonella can survive in slurry or lagoon wastewater $\leq 286 \mathrm{~d}$. Treatment methods such as the composting of dairy manure are used widely for treating dairy manure; however, the composting is also a slow process, and can be only applied for treating solid fractions of dairy manure. Currently, the U. S. Department of Agriculture (USDA) requires that there should be $\geq 120 \mathrm{~d}$ lag time between non-composted manure application and organic crop (with edible portions exposed to soil particles) harvesting (USDA 2000). While the existing USDA guidelines are useful for controlling the risk of pathogens in solid fractions of dairy manure, further science based information such as identifying the optimum retention period of dairy wastewater in storage lagoons can potentially assist in improving wastewater management. This study evaluated Salmonella inactivation in dairy manure under various thermal conditions; however, considering the growing number of Salmonella related food borne outbreaks and current ongoing food safety issues, additional studies focused on assessing Salmonella inactivation in both solid and liquid fractions of manure are required to improve manure management and its application as fertilizer.

\section{Conclusions}

The results of this study showed that there was a significant reduction in Salmonella concentrations over time particularly at elevated temperatures. The levels of Salmonella did not vary significantly within a short period of time (i.e. $\sim 4 \mathrm{~h}$ to $\sim 8 \mathrm{~h}$ ) at mesophilic temperature. At elevated temperatures (thermophilic temperatures), the first 30 min of incubation was important for reducing Salmonella levels. The observed regrowth requires additional verification. Therefore, there is further scope for studies to understand the degradation patterns of Salmonella at thermophilic as well as mesophilic temperatures. The outcomes of the study will help in improving the understanding of Salmonella inactivation in dairy wastewater as well as deriving improved dairy wastewater management practices.

\section{References}

Aitken, M. D., M. D. Sobsey, K. E. Blauth, M. Shehee, P. L. Crunk and G. W. Walters. 2005. "Inactivation of Ascaris suum and Poliovirus in Biosolids under Thermophilic Anaerobic Digestion Conditions." Environmental Science and Technology 39 (15): 5804-9.

Allievi, L., A. Colombi, E. Calcaterra and A. Ferrari. 1994. "Inactivation of Fecal Bacteria in Sewage Sludge by Alkaline Treatment." Bioresource Technology 49 (1): 25-30.

Amin-Nayyeri, M., M. H. Kianmehr, A. Arabhosseini, S. R. Hassan-Beygi and M. Aghbashlo. 2010. “Drying Behavior and Mathematical Modeling of Dairy Cattle Manure in a Convective Dryer." Applied Engineering in Agriculture 26 (4): 689-97.

Angelidaki, I., L. Ellegaard and B. K. Ahring. 1993. “A Mathematical Model for Dynamic Simulation of Anaerobic Digestion of Complex Substrates: Focusing on Ammonia Inhibition." Biotechnology and Bioengineering 42 (2): 159-66.

Bach, S. J., T. A. McAllister, D. M. Veira, V. P. J. Gannon and R. A. Holley. 2002. "Transmission and Control of Escherichia coli 0157:H7-A Review." Canadian Journal of Animal Science 82 (4): 475-90.

Baloda, S. B., L. Christensen and S. Trajcevska. 2001. "Persistence of a Salmonella enterica Serovar Typhimurium DT12 Clone in a Piggery and in Agricultural Soil Amended with Salmonella Contaminated Slurry." Applied and Environmental Microbiology 67:2859-62.

Barak, J. D., L. Gorski, P. Naraghi-Arani and A. O. Charkowski. 2005. "Salmonella enterica Virulence Genes Are Required for Bacterial Attachment to Plant Tissue." Applied and Environmental Microbiology 71 (10): 5685-91.

Beuchat, L. R. 2002. "Ecological Factors Influencing Survival and Growth of Human Pathogens on Raw Fruits and Vegetables." Microbes and Infection 4 (4): 413-23.

Brandon, J. R., W. D. Burge and N. K. Enkiri. 1977. "Inactivation by Ionizing Radiation of Salmonella enteritidis Serotype Montevideo Grown in Composed Sewage Sludge." Applied and Environmental Microbiology 33 (4): 1011-2.

CDC (Centers for Disease Control). 2014. "Surveillance for Foodborne Disease Outbreaks, United States, 2012, Annual Report." Atlanta, GA: Center for Disease Control and Prevention, U.S. Department of Health and Human Services.

Doyle, M. P. and M. C. Erickson. 2008. "Summer Meeting 2007: The Problems with Fresh Produce-An Overview." Journal of Applied Microbiology 105 (2): 317-30.

Dumas, C., S. Perez, E. Paul and X. Lefebvre. 2010. “Combined Thermophilic Aerobic Process and Conventional Anaerobic Digestion: Effect on Sludge Biodegradation and Methane Production." Bioresource Technology 101 (8): 2629-36.

Erickson, M. C., J. Liao, L. Ma, X. Jiang, and M. P. Doyle. 2014. "Thermal and Nonthermal Factors Affecting Survival of 
Salmonella and Listeria monocytogenes in Animal Manure Based Compost Mixtures." Journal of Food Protection 77 (9): 1512-8.

Garcia, R., J. Baelum, L. Fredslund, P. Santorum and C. S. Jacobsen. 2010. "Influence of Temperature and Predation on Survival of Salmonella enterica Serovar Typhimurium and Expression of invA in Soil and Manure Amended Soil." Applied and Environmental Microbiology 76 (15): 5025-31.

Georgakakis, D., D. M. Sievers, E. I. lannotti, S. P. Graef and J. F. Andrews. 1974. "Buffer Stability in Manure Digesters: Mathematical Modelling and Control of Anaerobic Digestion." Agricultural Wastes AICHE Symposium Series 136:101-31.

Harikishan, S. and S. Sung. 2003. "Cattle Waste Treatment and Class A Biosolid Production Using Temperature Phased Anaerobic Digester." Advances in Environmental Research 7 (3): 701-6.

Heinonen-Tanski, H., E. M. Niskanen, P. Salmela and E. Lanki. 1998. "Salmonella in Animal Slurry Can Be Destroyed by Aeration at Low Temperature." Journal of Applied Microbiology 85:277-81.

Himathongkham, S., S. Bahari, H. Riemann and D. Cliver. 1999. "Survival of Escherichia coli O157:H7 and Salmonella typhimurium in Cow Manure and Cow Manure Slurry." FEMS Microbiology Letters 178:251-7.

Himathongkham, S. and H. Riemann. 1999. “Destruction of Salmonella typhimurium, Escherichia coli O157:H7 and Listeria monocytogenes in Chicken Manure by Drying and /or Gassing With Ammonia." FEMS Microbiology Letters 171:179-82.

Hipsey, M. R., J. P. Antenucci and J. D. Brookes. 2008. "A Generic, Process Based Model of Microbial Pollution in Aquatic Systems." Water Resources Research 44 (7): W07408. doi:10.1029/2007WR006395

Hutchison, M. L., L. D. Walters, A. Moore and S. M. Avery. 2005. "Declines of Zoonotic Agents in Liquid Livestock Wastes Stored in Batches On-Farm." Journal of Applied Microbiology 99:58-65.

Hutchison, M. L., L. D. Walters, A. Moore, K. M. Crookes and S. M. Avery. 2004. "Effect of Length of Time before Incorporation on Survival of Pathogenic Bacteria Present in Livestock Wastes Applied to Agricultural Soil" Applied and Environmental Microbiology 70 (9): 5111-8.

Islam, M., J. Morgan, M. P. Doyle, S. C. Phatak, P. Millner and X. Jiang. 2004a. “Fate Of Salmonella enterica Serovar Typhimurium on Carrots and Radishes Grown in Fields Treated with Contaminated Manure Composts or Irrigation Water." Applied and Environmental Microbiology 70:2497-502.

Islam, M., J. Morgan, M. P. Doyle, S. C. Phatak, P. Millner and X. Jiang. 2004b. "Persistence of Salmonella enterica Serovar Typhimurium on Lettuce and Parsley and in Soils on which They Were Grown in Fields Treated with Contaminated Manure Composts or Irrigation Water." Foodborne Pathogens and Disease 1:27-35.
John, D. E. and J. B. Rose. 2005. “Review of Factors Affecting Microbial Survival in Groundwater." Environment Science \& Technology 39 (19): 7345-56.

Jones, P. W. 1976. “The Effect of Temperature, Solids Content and $\mathrm{pH}$ on the Survival of Salmonellas in Cattle Slurry." British Veterinary Journal 132:284-93.

Kearney, T. E., M. J. Larkin and P. N. Levett. 1993. "The Effect of Slurry Storage and Anaerobic Digestion on Survival of Pathogenic Bacteria." Journal of Applied Bacteriology 74:86-93.

Kim, J., M. W. Shepherd Jr. and X. Jiang. 2009. “Evaluating the Effect of Environmental Factors on Pathogen Regrowth in Compost Extract." Microbial Ecology 58 (3): 498-508.

Laven, R. A., A. Ashmore and C. S. Stewart. 2003. "Escherichia coli in the Rumen and Colon of Slaughter Cattle, with Particular Reference to E. coli O157." The Veterinary Journal 165 (1): 78-83.

Littell, R. C., G. A. Milliken, W. W. Stroup and R. D. Wolfinger. 1996. SAS System for Mixed Models. Cary, NC: SAS Institute Inc.

Maeda, K., D. Hanajima, R. Morioka and T. Osada. 2010. “Characterization and Spatial Distribution of Bacterial Communities within Passively Aerated Cattle Manure Composting Piles." Bioresource Technology 101 (24): 9631-7.

Murinda, S. E., L. T. Nguyen, H. M. Nam, R. A. Almeida, S. J. Headrick and S. P. Oliver. 2004. "Detection of Sorbitol-Negative and Sorbitol-Positive Shiga Toxin Producing Escherichia coli, Listeria monocytogenes, Campylobacter jejuni and Salmonella Spp. in Dairy Farm Environmental Samples." Foodborne Pathogens and Disease 1 (2): 97-104.

Natvig, E. E., S. C. Ingham, B. H. Ingham, L. R. Cooperband and T. R. Roper. 2002. "Salmonella enterica Serovar Typhimurium and Escherichia coli Contamination of Root and Leaf Vegetables Grown In Soils with Incorporated Bovine Manure." Applied and Environmental Microbiology 68:2737-44.

Nicholson, F. A., S. J. Groves and B. J. Chambers. 2005. “Pathogen Survival during Livestock Manure Storage and Following Land Application." Bioresource Technology 96:135-43.

Olsen, J. E. and H. E. Lasen. 1987. "Bacterial Decimation Times in Anaerobic Digestions of Animal Slurries." Biological Wastes 21 (3): 153-68.

Ongeng, D., C. Muyanja, A. H. Geeraerd, D. Springael and J. Ryckeboer. 2011. "Survival of Escherichia coli O157:H7 and Salmonella enterica Serovar Typhimurium in Manure and Manure-Amended Soil under Tropical Climatic Conditions in Sub-Saharan Africa." Journal of Applied Microbiology 110 (4): 1007-22.

Pandey, P. K., S. Biswas, V. K. Vaddella and M. L. Soupir. 2015. "Escherichia coli Persistence Kinetics in Dairy Manure at Moderate, Mesophilic, and Thermophilic Temperatures under Aerobic and Anaerobic Environments." Bioprocesss and Biosystems Engineering 38 (3): 457-67. 
Pandey, P. K., P. H. Kass, M. L. Soupir, S. Biswas and V. P. Singh. 2014. "Contamination of Water Resources by Pathogenic Bacteria." AMB Express 4:51. doi: 10.1186/s13568-014-0051-x

Pandey, P. K. and M. L. Soupir. 2011. "Escherichia coli Inactivation Kinetics in Anaerobic Digestion of Dairy Manure under Moderate, Mesophilic, and Thermophilic Temperatures." AMB Express 1:18 doi:10.1186/2191-0855-1-18.

Pandey, P. K., M. L. Soupir, M. Haddad and J. J. Rothwell. 2012. "Assessing the Impacts of Watershed Indexes and Precipitation on Spatial In-Stream E. coli Concentrations." Ecological Indicators 23:641-52.

Pell, A. N. 1997. "Manure And Microbes: Public and Animal Health Problem?" Journal of Dairy Science 80:2673-81.

Popat, S. C. , M. V. Yates and M. A. Deshusses. 2010. “Kinetics of Inactivation of Indicator Pathogens during Thermophilic Anaerobic Digestion." Water Resources 44 (20): 5965-72.

Rhoades, J. R., G. Duffy and K. Koutsoumanis. 2009. “Prevalence and Concentration of Verocytotoxigenic Escherichia coli, Salmonella enterica and Listeria monocytogenes in the Beef Production Chain: A Review." Food Microbiology 26 (4): 35776.

Shepherd, M. W. Jr., R. Singh, J. Kim and X. P. Jiang. 2010. “Effect of Heat-Shock Treatment on the Survival of Escherichia coli O157:H7 and Salmonella enterica Typhimurium in Dairy Manure Co-Composted with Vegetable Wastes under Field Conditions." Bioresource Technology 101:5407-13.

Sinton, L. W., R. R. Braithwaite, C. H. Hall and M. L. Mackenzie. 2007. "Survival of Indicator and Pathogenic Bacteria in Bovine Feces on Pasture." Applied and Environmental Microbiology 73 (24): 7917-25.

Smith, B. P. 2002. "Salmonellosis in Ruminants." In Large Animal Internal Medicine, edited by B.P. Smith, 775-9. St. Louis, MO: Mosby Year Book Inc.

Soupir, M. L., S. Mostaghimi, E. R. Yagow, C. Hegedorn and D. H. Vaughan. 2006. "Transport of Fecal Bacteria from Poultry Litter and Cattle Manures Applied to Pastureland." Water, Air, and Soil Pollution 169 (1): 125-36.

Tauxe, R. V. 1997. “Emerging Foodborne Diseases: An Evolving Public Health Challenge." Emerging Infectious Diseases 3 (4): 425-34.

Toth, J. D., H. W. Aceto, S. C. Rankin and Z. Dou. 2011. “Survival Characteristics of Salmonella enterica Serovar Newport in a Dairy Lagoon, Field Soil, and Compost Pile." Journal of Dairy Science 94 (10): 5238-46.

Toth, J. D., H. W. Aceto, S. C. Rankin and Z. Dou. 2012. "Accelerating the Deactivation of Salmonella enterica Serovar Newport and Escherichia coli O157:H7 in Dairy Manure by Modifying pH or Temperature." The Open Waste Management Journal 5:11-8.

Toth, J. D., H. W. Aceto, S. C. Rankin and Z. Dou. 2013. “Short Communication: Survey of Animal Borne Pathogens in the Farm Environment of 13 Dairy Operations." Journal of Dairy Science 96 (9): 5756-61.

USDA (U.S. Department of Agriculture). 2000. National Organic Program."Washington DC: Agricultural Marketing Service, U.S. Department of Agriculture. 7 CFR Part 205:203

USDA (U.S. Department of Agriculture). 2009. Manure Use for Fertilizer and for Energy. Report to Congress. Washington DC: Economic Research Service, U.S. Department of Agriculture.

USDA (U.S. Department of Agriculture). 2014. Cattle Inventory. Washington, DC: U.S. Department of Agriculture National Agricultural Statistics Service (NASS). http://usda.mannlib.cornell.edu/usda/nass/Catt//2010s/2014/Catt-01-31-2014.pdf.

USEPA (U.S. Environmental Protection Agency). 2012. Guidance Specifying Management Measures For Sources Of Nonpoint Pollution In Coastal Waters. Washington, DC: U.S. Environmental Protection Agency Office of Water.

USFDA (U.S. Food and Drug Administration). 2014a. Bacteriological Analytical Manual, 8th ed., revision A. Silver Spring, MD: U. S. Food and Drug Administration.

http://www.fda.gov/food/foodscienceresearch/laboratorymethods/ucm2006949.htm.

USFDA (U.S. Food and Drug Administration). 2014b. Food Safety for Moms-to-Be: Medical Professionals-Foodborne Pathogens. Silver Spring, MD: U.S. Food and Drug Administration. http://www.fda.gov/food/resourcesforyou/healtheducators/ucm091681.htm.

Wang, G., T. Zhao and M. P. Doyle. 1996. “Fate of Enterohemorrhagic Escherichia coli 0157:H7 in Bovine Feces." Applied and Environmental Microbiology 62:2567-70.

Wells, S. J., P. J. Fedorka-Cray, D. A. Dargatz, K. Ferris and A. Green. 2001. "Fecal Shedding of Salmonella spp by Dairy Cows on Farm and at Cull Cow Markets." Journal of Food Protection 64 (1): 3-11.

You, Y., S. C. Rankin, H. W. Aceto, C. E. Benson, J. D. Toth and Z. Dou. 2006. "Survival of Salmonella enterica Serovar Newport in Manure and Manure-Amended Soils." Applied and Environmental Microbiology 72:5777-83.

Zhao, T., M. P. Doyle, J. Shere and L. Garber. 1995. “Prevalence of Enterohemorrhagic Escherichia coli O157:H7 in a Survey of Dairy Herds." Applied and Environmental Microbiology 61:1290-3. 